\title{
PETROGRAPHY, GEOCHEMISTRY AND INDUSTRIAL QUALITY OF THE ETONO LIMESTONE IN UGEP SOUTHWEST, SOUTHEASTERN NIGERIA.
}

\author{
J. U. ODEY, A. C. UGWU AND B. N. EKWUEME
}

(Received 23 July 2021; Revision Accepted 6 September 2021)

\begin{abstract}
Petrographic and geochemical analyses were carried out on limestones occurring in Etono, Southwest Ugep, Southeastern Nigeria to determine their chemical composition, industrial uses and classification. Samples of limestone in the area were subjected to petrographic study and analyzed geochemically using Inductively Coupled Plasma Atomic Emission Spectrometry (ICP-AES) and X-Ray Fluorescence (XRF) techniques. The petrographic analysis reveals that the Etono limestone contains high percentage of carbonate materials with scanty organic remains and patches of iron. The bulk- rock composition of the limestone shows that the average $\mathrm{SiO}_{2}=9.02 \%, \mathrm{Al}_{2} \mathrm{O}_{3}=1.95 \%$, $\mathrm{Fe}_{2} \mathrm{O}_{3}=2.08 \%, \mathrm{MgO}=0.39 \%, \mathrm{~K}_{2} \mathrm{O}=0.47 \%, \mathrm{Na}_{2} \mathrm{O}=0.00 \%, \mathrm{CaO}=47.92 \%, \mathrm{SO}_{2}=0.24 \%$ and $\mathrm{LOI}=37.37 \%$. The limestone is classified based on their moderately high $\mathrm{CaO}, \mathrm{SiO}_{2}$ and $\mathrm{LO}$ and very low $\mathrm{MgO}$. The mean $\mathrm{CaO}(47.92 \%)$ of Etono Limestone is high relative to the mean $\mathrm{CaO}$ of Agoi Ibami Limestone (43.83\%) but low relative to the Mfamosing Limestone $(55.30 \%)$ and the mean $\mathrm{SiO}_{2}$ values of $9.02 \%$ is high relative to Mfamosing Limestone $(0.38 \%)$ but low relative to Agoi Ibami Limestone (13.93\%). Results of the geochemical investigation reveal a shallow marine environment of deposition (EOD) for Etono Limestone. The higher values of $\mathrm{CaO}$ and $\mathrm{LOI}$ and lower values of $\mathrm{SiO}_{2}$ of the limestone suggest that it can be used for cement production, building stone, filler and agricultural purposes.
\end{abstract}

KEY WORDS; Etono,Limestone, Agoi Ibami, Mfamosing and Cement.

\section{INTRODUCTION}

Carbonate rocks constitute about $50 \%$ of the world's hydrocarbon reservoir rocks and among these, limestone is widely used as raw materials in the chemical, metallurgical and construction industries. The quality and the usefulness of limestone deposit is largely dependent on the geological setting, physico-chemical, mechanical and mineralogical characteristics of the rock (Ehiola et al, 2016).

An evaluation of usefulness of a limestone deposit entails a geological field investigation and laboratory analyses of representative samples. Naturally, limestone carries varied suite of impurities such as $\mathrm{SiO}_{2}$, $\mathrm{MgO}$ and $\mathrm{Fe}_{2} \mathrm{O}_{3}$, whose geochemical concentration determines its industrial applications (Harrison et al., 1990). Most limestone industrial applications consider the $\mathrm{CaO}$ and $\mathrm{MgO}$ contents as fundamental criteria for its chemical purity or grade classification (Ekwueme, 1985).

In accord with the global increase in the applications of geological models for exploration and exploitation of sedimentary rocks. The area falls into the Calabar Flank of Murat

(1972). mineral resources; geochemical models revealing limestone's chemical purity can be used as a tool to appraise the spatio-temporal distribution of limestone purity throughout the deposit (Harrison et al., 1990). The modelling approach is targeted at locating anomalous concentration(s) of high purity limestone or other pathfinder elements characterizing the host lithology. This method may form a basis for comparison of data for limestone of other geological settings all over the earth. In this contribution, the chemical composition of Etono limestone is discussed and its industrial quality based on the geochemistry assessed.

Etono falls into the geological survey sheet 314 (Ugep SW) and is located in central part of Cross River State within Latitudes $5^{0} 38^{\prime} \mathrm{N}$ to $5^{\circ} 41^{\prime} \mathrm{N}$ and Longitudes $8^{0} 02^{\prime} \mathrm{E}$ to $8^{0} 08^{\prime} \mathrm{E}$ (Fig. 1). The map area consists of smaller communities and farmlands. Etono and its environs belong to the Mfamosing Limestone of the Cretaceous sedimentary basin of southeastern Nigeria. Etono lies within the eastern part of the southern Benue Trough which consists of mainly

J. U. ODEY, Department of Geology, University of Calabar, Calabar, Nigeria

A. C. UGWU, Department of Geology, University of Calabar, Calabar, Nigeria

B. N. EKWUEME, Department of Geology, University of Calabar, Calabar, Nigeria 


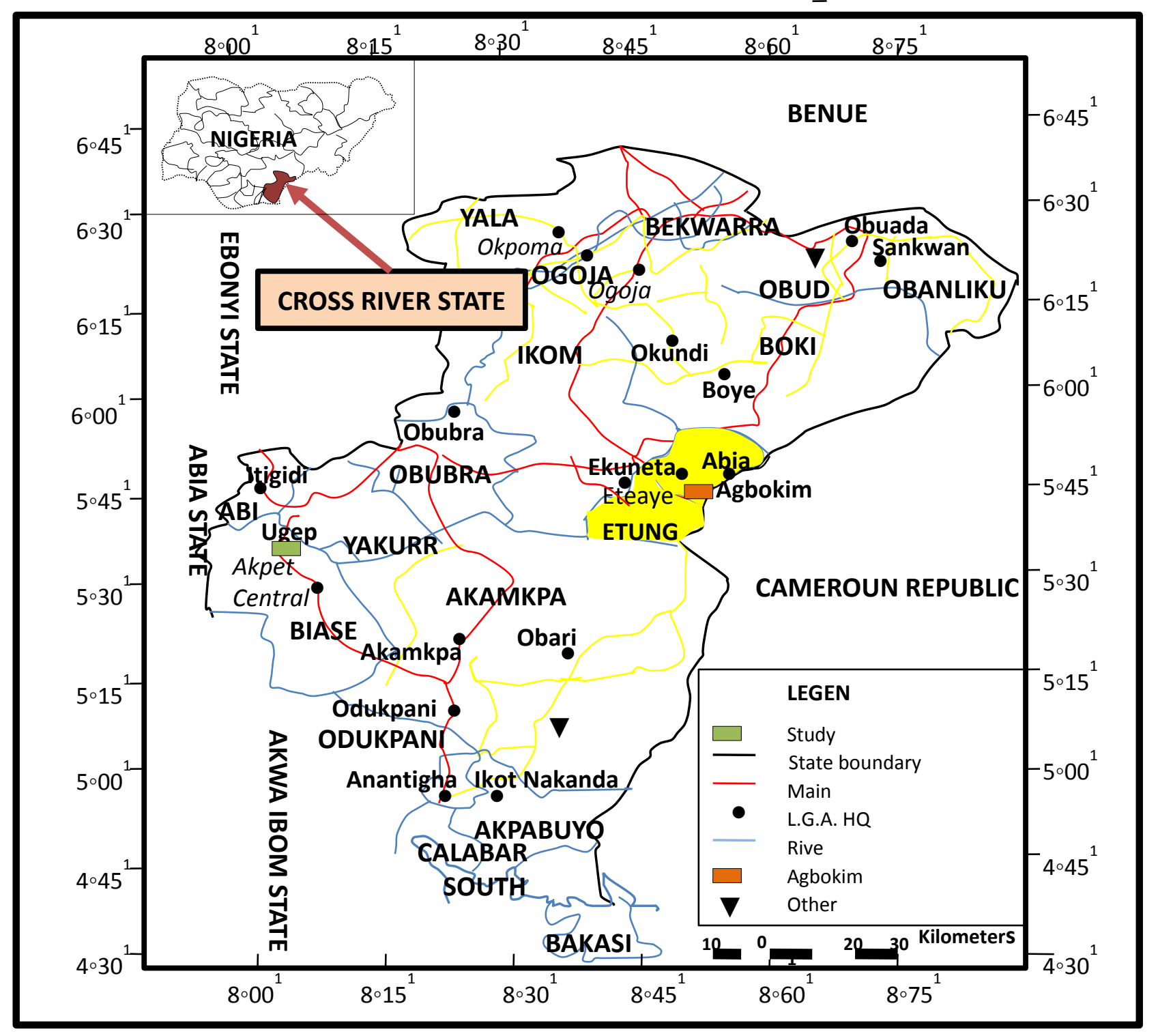

Map of cross River State showing the study area (Resource Gate). 
The term Calabar Flank was first introduced by Murat (1972) as part of the Southern Nigeria sedimentary basin that is bounded by the Oban Massif to the North and the Calabar Hinge line delineating the Niger Delta Basin in the South (Nyong and Ramanathan 1985). It is also separated from the Ikpe platform to the West by a NE-SW trending fault. In the East, it extends up to the Cameroun Volcanic ridge (Fig. 2). It served as the gateway to all marine transgression into the Benue Trough and is located between two hydrocarbons provinces, the Tertiary Niger Delta and Cretaceous Douala basin in Cameroun (Petters and Reijers, 1987).

Structurally, the Calabar Flank consists of basement horsts and grabens that aligned in a NW-SE direction like other South Atlantic marginal basin in West Africa (Petters and Reijers, 1987). The Calabar Flank shows striking stratigraphic similarities with other coeval marginal basin of the South Atlantic Ocean and the first marine incursion in middle Albian accounted for the deposition of Mfamosing Limestone particularly on the horst and relatively stable platform areas and their Flanks (Adeleye and Fayose, 1978). Sedimentation started in the Calabar Flank with deposition of fluviodeltaic clastics of probably Aptian age on the Precambrian crystalline basement complex, the Oban
Massif (Adeleye and Fayose, 1978). The stratigraphy of Calabar Flank begins with the Awi Sandstone at the base overlain by the Mfamosing Limestone (the study area is part of this Formation). The Mfamosing Limestone is overlain by the thick sequence of black to grey shale unit, the Ekenkpon Shale Formation (Petters and Reijers, 1987). The Formation is characterized by minor intercalation of marls; calcareous mudstone and oysters beds. This shale unit was deposited during the late Cenomanian-Turonian time. The Ekenkpon Shale is overlain by a thick marl unit; the New Netim Marl (Adeleye and Fayose, 1978). This unit is nodular and shaley at the base and is interbedded with thin layer of shales in the upper section. The presence of foraminifera suggest early Concianian age for the marl (Nyong and Ramanathan 1985).

The New Netim marl is unconformably overlain by carbonaceous dark grey shale and the Nkporo Formation (Reyment, 1965). The shale unit was deposited during the Late Campanian-Maastrichtian times. The Nkporo shale caps the Cretaceous sequence in the Calabar Flank. The Nkporo Shale sequence is overlain by a pebbly sandstone unit of the Tertiary Benin Formation.

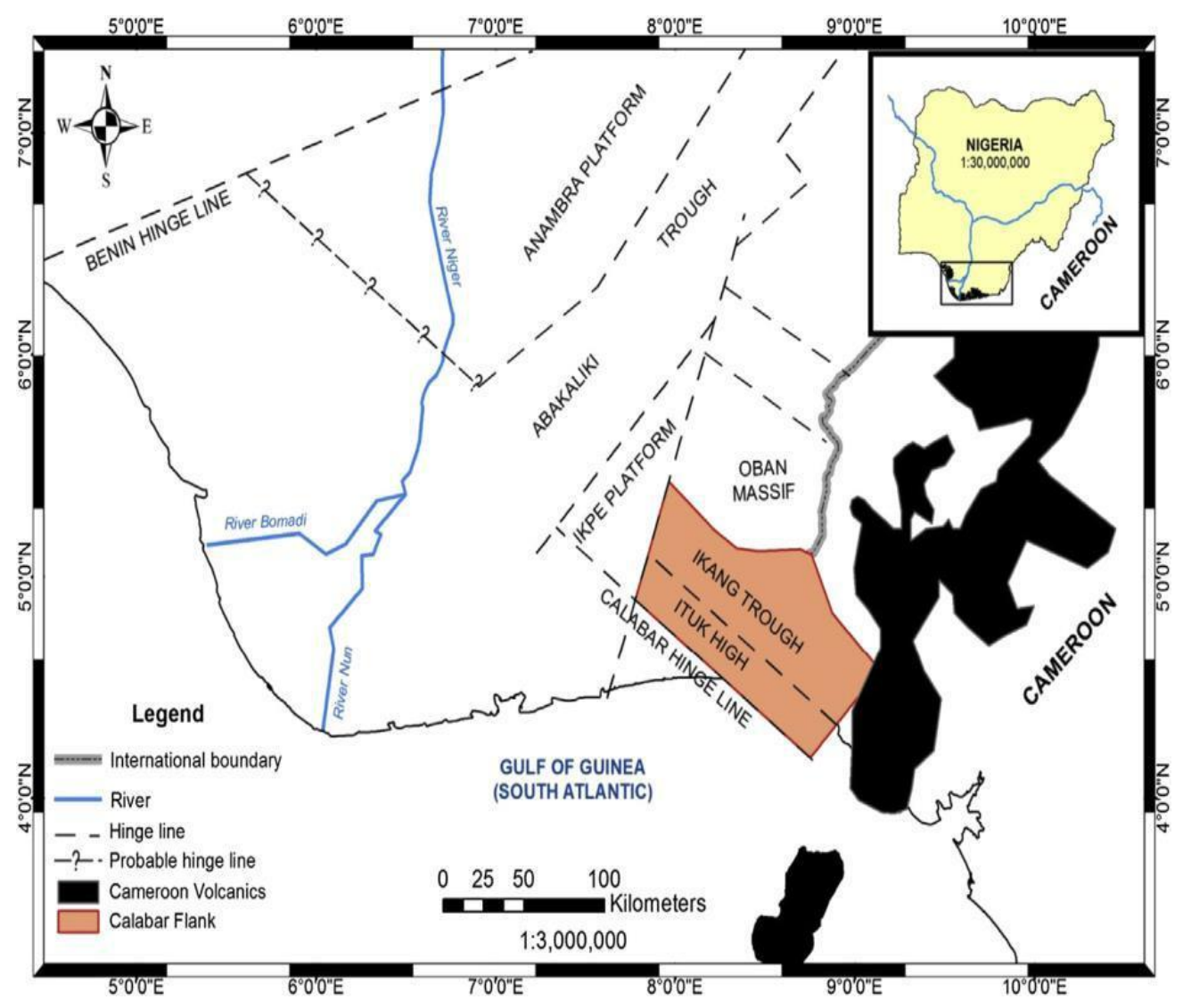

FIG. 2: Structural elements of the Calabar Flank and adjacent areas (After Nyong and Ramanathan, 1985) 
Field occurrence

Southwest Ugep area is composed of basement rocks overlain by Cretaceous Sedimentary rocks of which Etono Limestone belongs (Fig. 3).

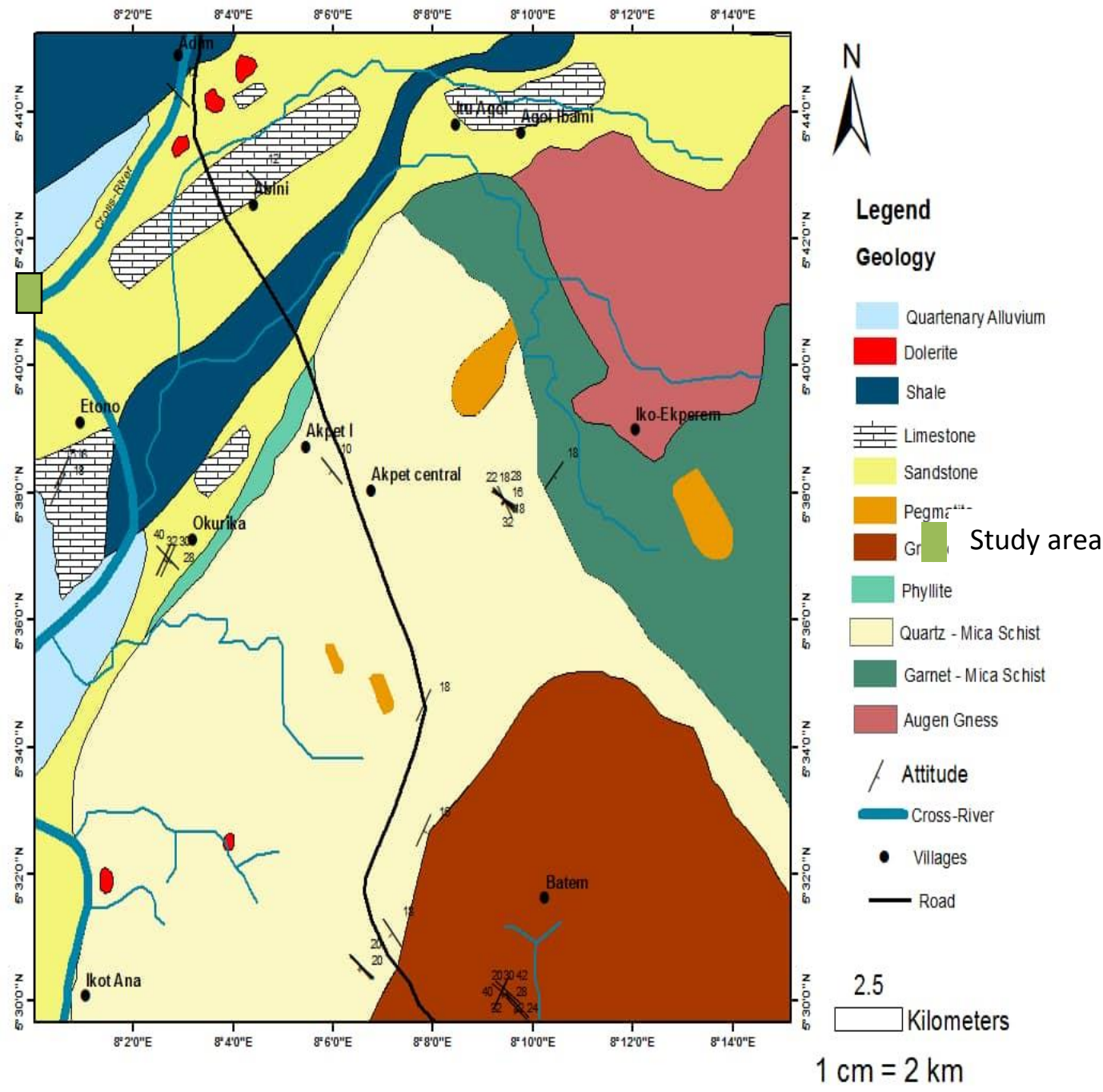

FIG. 3: Geological map of Ugep SW (Adapted from Ugwu, 2021)

Limestone is wide spread in the Etono area. The limestone occurs as ridges. They are thickly bedded and have grey to somewhat whitish chalky colour. They are hard and can easily be scratched. It has a crystalline

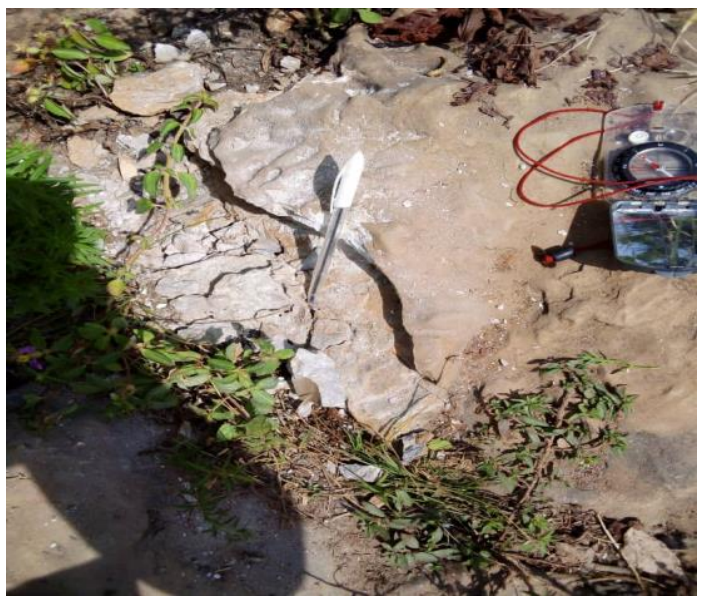

Plate 1: Thickly bedded limestone in the study area. texture, bioturbated and fossiliferous. Some of the fossils encountered are brachiopods, gastropods and bivalves. The rock effervesces on the application of dilute hydrochloric acid.

Plate 2: Limestone outcrop in the study area. 


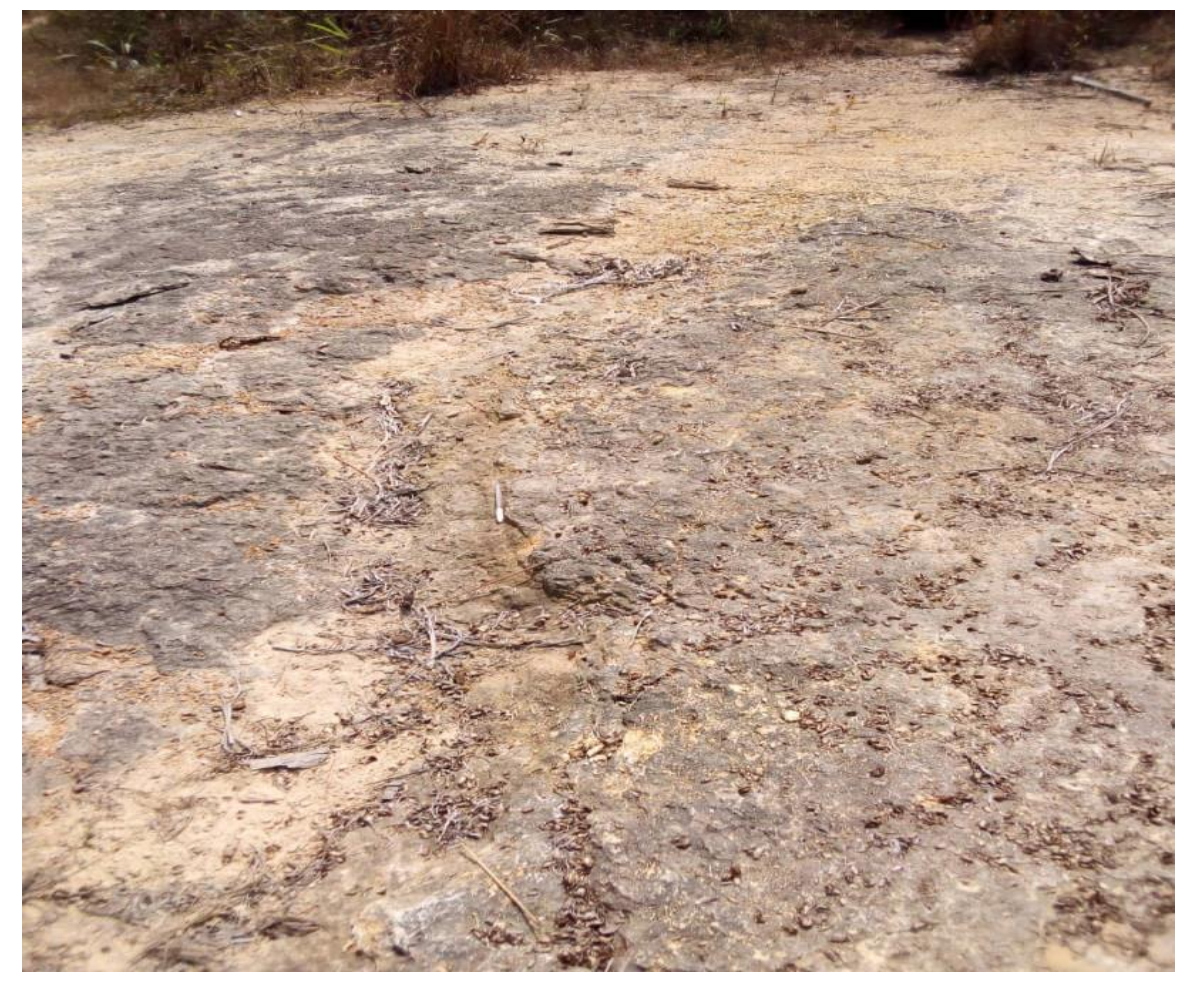

Plate 3: Limestone within Etono with algal stromatolitic look.

\section{Petrography}

Petrographic analysis was carried out on six (6) limestone samples (Table 1). The limestone contains high percentage of carbonate materials. Organic remains are generally scanty with occasional patches of iron. Grains of quartz occur in the mode. Micrite is abundant in all the samples. The matrix of the limestone is the mud while calcite forms the cement (Fig. 4 and 5).
Table 1 shows the modal composition of the limestones. The petrography is reflective of the sedimentation style that led to the deposition of the Etono Limestone. The limestone has abundant micrite and megascopic shell fragments and grains of quartz in a matrix of mud and calcite cement (Todd, 1968; Pettijohn, 1984). It can therefore be used as building stone

Table 1: Modal composition of Etono Limestone

\begin{tabular}{|l|l|l|l|l|l|l|}
\hline Mineral & Sample 1 & Sample 2 & Sample 3 & Sample 4 & Sample 5 & Sample 6 \\
\hline Quartz & 20 & 15 & 20 & 10 & 25 & 20 \\
\hline Carbonate mud & 65 & 70 & 60 & 70 & 55 & 55 \\
\hline Organic remains & 10 & 5 & 10 & 15 & 10 & 20 \\
\hline
\end{tabular}

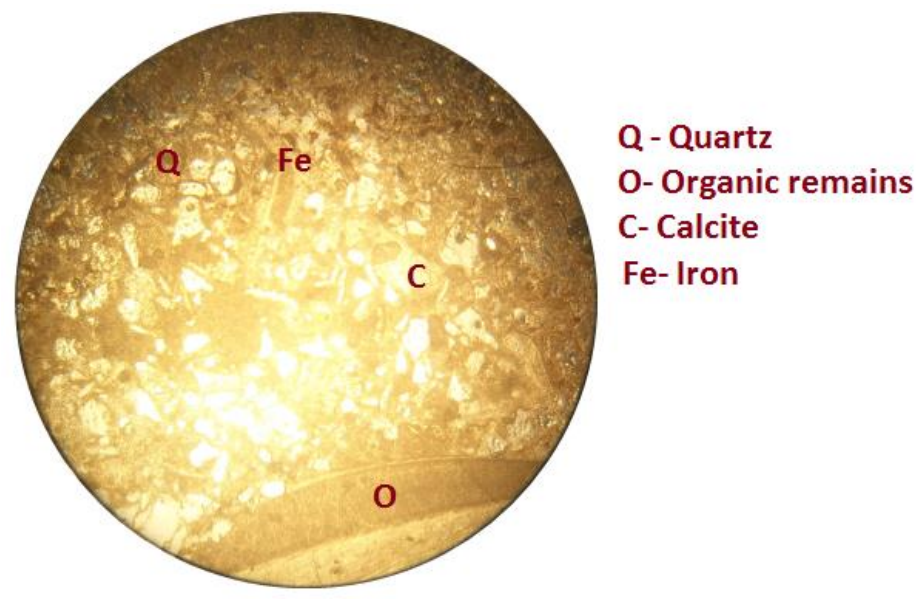

FIG. 4. Photomicrograph of Etono Limestone (PPL, X16). 


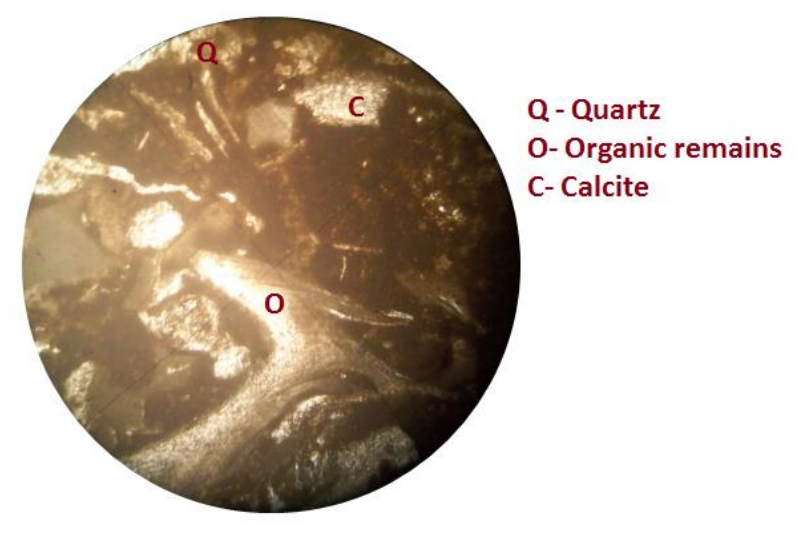

FIG. 5: Photomicrograph of Etono Limestone (PPL, X12)

\section{GEOCHEMISTRY}

Samples of Etono Limesone were analyzed to determine their major and minor element compositions. The concentration of the major and minor elements is presented in Table 2.

Table 2: Chemical composition of Etono Limestone.

\begin{tabular}{|l|l|l|l|l|l|l|l|l|l|l|l|l|l|}
\hline \multirow{2}{*}{ Sample } & \multicolumn{9}{|l|}{ Chemical composition (\%) } & \multicolumn{3}{l|}{ Moduli } \\
& $\mathbf{S i O}_{2}$ & $\mathbf{A l 2 O 3}$ & $\mathbf{F e}_{2} \mathbf{O}_{3}$ & $\mathbf{C a O}$ & $\mathbf{M g O}$ & $\mathbf{S O}_{2}$ & $\mathbf{K}_{2} \mathbf{O}$ & $\mathbf{N a}_{2} \mathbf{O}$ & LOI & TOTAL & LSF & SM & AM \\
\hline Sample 1 & 3.52 & 1.05 & 1.79 & 51.30 & 0.49 & 0.19 & 0.13 & 0.01 & 41.38 & 90.33 & 418.97 & 1.24 & 0.59 \\
\hline Sample 2 & 14.45 & 3.05 & 2.57 & 44.15 & 0.47 & 0.54 & 0.62 & 0.01 & 33.72 & 71.41 & 96.53 & 2.57 & 1.19 \\
\hline Sample 3 & 8.72 & 2.36 & 4.42 & 44.77 & 0.37 & 0.35 & 0.51 & 0.00 & 37.63 & 79.36 & 148.85 & 1.29 & 0.53 \\
\hline Sample 4 & 5.04 & 1.43 & 1.69 & 49.70 & 0.43 & 0.13 & 0.20 & 0.00 & 40.47 & 89.27 & 294.16 & 1.62 & 0.85 \\
\hline Sample 5 & 9.33 & 1.88 & 1.49 & 51.35 & 0.40 & 0.13 & 0.51 & 0.00 & 34.48 & 84.27 & 175.15 & 2.77 & 1.26 \\
\hline Sample 6 & 13.07 & 1.93 & 0.49 & 46.23 & 0.19 & 0.11 & 0.85 & 0.00 & 36.55 & 80.89 & 117.98 & 5.40 & 3.97 \\
\hline Min & 3.52 & 1.05 & 0.49 & 44.15 & 0.19 & 0.11 & 0.13 & 0.00 & 33.72 & 71.41 & 96.53 & 1.24 & 0.53 \\
\hline Max & 14.45 & 3.05 & 4.42 & 51.35 & 0.49 & 0.54 & 0.85 & 0.01 & 41.38 & 90.33 & 418.97 & 5.40 & 3.97 \\
\hline Mean & 9.02 & 1.95 & 2.08 & 47.92 & 0.39 & 0.24 & 0.47 & 0.00 & 37.37 & 82.59 & 208.61 & 2.48 & 1.40 \\
\hline
\end{tabular}

The $\mathrm{SiO}_{2}$ content of the samples has a mean value of 9.02 and ranges from $3.52-14.45 \%$. The $\mathrm{SiO}_{2}$ values vary from one location to another with sample 2 having the highest value (14.45\%) while sample 1 has the lowest value (3.52\%).

The $\mathrm{Al}_{2} \mathrm{O}_{3}$ content of the samples has a mean value of 1.95 and ranges from $1.05-3.05 \%$. The $\mathrm{Al}_{2} \mathrm{O}_{3}$ values vary from one location to another with sample 2 having the highest value $(3.05 \%)$ while sample 1 has the lowest value $(1.05 \%)$

The $\mathrm{Fe}_{2} \mathrm{O}_{3}$ content of the samples has a mean value of 2.08 and ranges from $0.49-4.42 \%$. The $\mathrm{Fe}_{2} \mathrm{O}_{3}$ values vary from one location to another with sample 3 having the highest value $(4.42 \%)$ while sample 6 has the lowest value $(0.49 \%)$.

The $\mathrm{CaO}$ content of the samples has a mean value of $47.92 \%$ and ranges from $44.15-51.35 \%$. The $\mathrm{CaO}$ values vary from one location to another with sample 1 having the highest value $(51.30 \%)$ while sample 2 has the lowest value $(44.15 \%)$.

The $\mathrm{MgO}$ content of the samples has a mean value of 0.39 and ranges from $0.19-0.49 \%$. The $\mathrm{MgO}$ values vary from one location to another with sample 1 having the highest value $(0.49 \%)$ while sample 1 has the lowest value $(0.19 \%)$.
The $\mathrm{SO}_{2}$ content of the samples has a mean value of $0.24 \%$ and ranges from $0.11-0.54 \%$. The $\mathrm{SO}_{2}$ values vary from one location to another with sample 2 having the highest value $(0.54 \%)$ while sample 6 has the lowest value $(0.11 \%)$.

The $\mathrm{K}_{2} \mathrm{O}$ content of the samples has a mean value of $0.47 \%$ and ranges from $0.11-0.85 \%$. The $\mathrm{K}_{2} \mathrm{O}$ values vary from one location to another with sample 6 having the highest value $(0.82 \%)$ while sample 1 has the lowest value $(0.11 \%)$.

Most of the samples show very poor $\mathrm{Na}_{2} \mathrm{O}$ recovery (below detection limit). However the samples have a mean value of $0.00 \%$ and ranges from $0.00-0.01 \%$. The $\mathrm{Na}_{2} \mathrm{O}$ values vary from one location to another with samples 1 and 2 having the highest value $(0.01 \%)$ while samples 3, 4, 5 and 6 have the lowest values $(0.00 \%)$.

The Loss on Ignition of the samples has a mean value of $37.37 \%$ and ranges from $33.72 \%-41.38 \%$. The LOI values reflects the $\mathrm{CaO}$ content of the limestone and vary from one location to another with sample 1 having the highest value $(41.38 \%)$ while sample 2 has the lowest value $(33.72 \%)$.

\section{DISCUSSION}

The geochemical composition of the Etono Limestone is related to the petrography. Comparison can be 
established between Table 1 and 2. The mean $\mathrm{CaO}$ $(47.92 \%)$ of limestone in the study area compares well with that of Tse-Kuchi Limestone (Makurdi-50.06\%), Gboko Limestone (48.88\%) and Nkalagu Limestone (49.74\%) (Ikhane et al., 2009) but the mean CaO of Agoi Ibami Limestone is very low (43.83\%). The limestone is almost pure limestone with $\mathrm{CaO}$ and LOI content $(50.89$ and $37.37 \%$ respectively) (Olaide, 1988) but is lower than that of Mfamosing Limestone (55.30\%) (Ekwueme, 1985), Shagamu (59.20\%,) and Shapfell Limestone $(54.72 \%)$. The Etono Limestone purity was compared to different limestones outcropping around Nigeria and beyond (Table 3).
The mean $\mathrm{SiO}_{2}$ values of $9.02 \%$ is high relative to other limestone deposits in Nigeria including Mfamosing Limestone $(0.38 \%)$, Middle belt limestone $(0.535 \%)$, Shapfell Limestone (0.71\%), Nkalagu Limestone (3.36\%) and Shagamu Limestone (5.70\%). However, it is lower than that of Gboko Limestone (9.78\%) and Agoi Ibami Limestone (13.93\%). The high silica content is attributed to the influx of terrigenous materials during the deposition of the Etono Limestone. However, the terrigenous inputs were not so much to change the composition of the limestone to marl or sandy limestone (cf.

Ekwueme

1987).

Table 3: Comparison of Etono Limestone with other Limestones in Nigeria and Elsewhere

\begin{tabular}{|c|c|c|c|c|c|c|c|c|c|c|c|}
\hline & $\mathrm{SiO}_{2}$ & $\mathrm{Al}_{2} \mathrm{O}_{3}$ & $\mathrm{Fe}_{2} \mathrm{O}_{3}$ & MgO & $\mathrm{CaO}$ & $\mathrm{Na}_{2} \mathrm{O}$ & $\mathrm{K}_{2} \mathrm{O}$ & $\mathrm{TiO}_{2}$ & $\mathbf{P}_{2} \mathbf{O}_{5}$ & MnO & LOI \\
\hline This study & 9.02 & 1.95 & 2.08 & 0.39 & 47.92 & 0.00 & 0.47 & & & & 37.37 \\
\hline $\begin{array}{l}\text { Relatively Pure } \\
\text { Limestone (Olaide, } \\
\text { 1988) }\end{array}$ & 1.88 & 0.83 & 0.26 & 2.75 & 50.89 & 0.06 & 0.01 & 0.01 & 0.01 & 0.01 & \\
\hline \begin{tabular}{|l|} 
Mfamosing \\
Limestone \\
(Ekwueme, 1985) \\
\end{tabular} & 0.38 & 0.78 & 0.09 & 0.29 & 55.30 & 0.03 & 0.03 & 0.01 & 0.08 & 0.07 & \\
\hline $\begin{array}{l}\text { Agoi Ibami } \\
\text { Limestone } \\
\text { (Ekwueme, 1985) } \\
\end{array}$ & 13.93 & 2.80 & 0.65 & 0.50 & 43.83 & 0.17 & 1.06 & 0.05 & 0.16 & 0.11 & \\
\hline $\begin{array}{l}\text { Nkalagu (Ikhane } \\
\text { et al., 2009) }\end{array}$ & 3.36 & 1.09 & 1.70 & 1.52 & 50.06 & 0.02 & 0.05 & 0.08 & 0.90 & 0.10 & 40.4 \\
\hline $\begin{array}{l}\text { Tse-Kucha } \\
\text { Limestone (Brand, } \\
\text { 1983) }\end{array}$ & 6.40 & 2.20 & 1.40 & 0.70 & 48.20 & 0.09 & 0.48 & 0.11 & 0.11 & 0.13 & 40.12 \\
\hline $\begin{array}{l}\begin{array}{l}\text { Nkalagu } 2 \text { (Petters, } \\
\text { 1978) }\end{array} \\
\end{array}$ & 5.90 & 1.30 & 0.77 & 0.99 & 49.74 & & & & & & \\
\hline 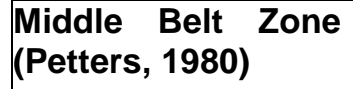 & 0.53 & 0.07 & 0.04 & 1.77 & 52.17 & 0.19 & 0.13 & 0.01 & & 0.07 & 44.97 \\
\hline $\begin{array}{l}\text { Gboko Limestone } \\
\text { (Petters, 1982) }\end{array}$ & 9.78 & 1.48 & 2.20 & 1.99 & 48.88 & 0.05 & 0.01 & & & & 36.57 \\
\hline \begin{tabular}{|l} 
Shagamu \\
Limestone \\
(Brand,1983)
\end{tabular} & 5.70 & & & & 59.20 & & & & & & \\
\hline $\begin{array}{l}\text { Shapfell Limestone } \\
\text { UK (Downie, Walden } \\
\text { and John, 1982) }\end{array}$ & 0.71 & 0.52 & 0.34 & 0.35 & 54.72 & & & & & & \\
\hline
\end{tabular}

Relative to the concentration of alumina, magnesium oxide and sodium oxide concentrations are low with mean values of $1.95 \%, 0.39 \%$ and $0.00 \%$ respectively. The low concentration of alumina suggests a low energy environment. The skeletal debris of marine invertebrate has low magnesium with increasing level in the phyla (Chave, 1954). The Etono Limestone is rich in brachiopods, gastropods, bivalves, and shell fragments of echinoids which are typical of an open shelf environment (Ehinola et al., 2012). The presence of these invertebrates could be responsible for the low level of magnesium in shallow marine environment.

Loss on Ignition (LOI) reveals the content of volatiles present in the limestone deposits. High LOI value is indicative of high volatile content suggesting a high carbonate content since it is synonymous with the evolvement of carbon dioxide after heating at $1000^{\circ} \mathrm{C}$ (Ehinola et. al., 2016). The fluctuation (increase or decrease) in $\mathrm{Fe}_{2} \mathrm{O}_{3}$ content may have a relationship with the terrigenous influx associated with high iron bearing solutions. Higher amount of $\mathrm{Fe}_{2} \mathrm{O}_{3}$ in carbonate rocks reduces the absorption capacity which in turn lowers the rate of ignition of the samples (Ehinola et al., 2012).

\section{QUALITY IMPLICATIONS}

The results of the geochemical analysis (Table 1 ) reflect the environment of deposition (EOD) and carbonate build up style. The rock samples can best be classified as limestone due to the percentage of silica (low silicate), magnesium oxide ( $\mathrm{MgO})$ and high calcium oxide $(\mathrm{CaO})$. The relatively high level of $\mathrm{CaO}$, moderate values of $\mathrm{SiO}_{2}$ and low level $\mathrm{MgO}$ indicate a moderate degree of purity of the limestone, hence its suitability as raw material for cement production. This is consistent with the study of Ekwueme (1985), Abdulraman and Ayuba (2007), Abimbola and Akande (1996). Impurities 
in the raw material which may affect its quality for cement production include magnesium, fluorine, phosphorous, lead, zinc, alkalis and sulphide. Most national specifications for ordinary Portland cement require that the cement should contain less than 6\% $\mathrm{MgO}$. Other chemical specifications may limit $\mathrm{SO}_{3}$ and $\mathrm{P}_{2} \mathrm{O}_{5}$ to less than $1 \%$ and total alkalis to less than $0.6 \%$ (Harrison, Hudson and Cannel, 1990).

According to Seedman and Barlow (1989), several parameters including cement type and grain size directly affect building stone durability. It is therefore, evident that from the petrographic analysis of the Etono limestone, they fit into the coarse spar-cemented limestone and therefore can be used as building stone. Many uses of limestone powders such as in carpet backing, asphalt and coal mine dust do not require pure limestone $\left(95 \% \mathrm{CaCO}_{3}\right)$. Consequently the limestone under reference may be utilized for such purposes as fillers.

Requirements for agricultural limestone are not very rigid. The main function is to reduce soil acidity, although it may also be used to increase levels of calcium or magnesium in the soil. Therefore, the Etono Limestone is suitable for agricultural use.

\section{CONCLUSION}

Limestone remains one of the industrial minerals with global use. Limestone is quarried for cement production in some parts of Nigeria. However, the suitability of limestone production depends on its chemistry. This helps in the prediction of its purity. In this regards, a petrographic and geochemical analyses were carried out to have a better understanding of the limestone at Etono.

The petrographic analysis reveals that the rock unit contains high percentage of carbonate materials. Organic remains are generally scanty with occasional patches of iron. Quartz was easily identified. The geochemical investigation of the Etono Limestone shows that $\mathrm{CaO}$ is moderately high and the prevailing concentration of $\mathrm{CaO}$ with respect to $\mathrm{SiO}_{2}$ reveals its suitability for cement production. It can also be used as building stone, for filler purposes and for agriculture. The relationship between $\mathrm{CaO}, \mathrm{Al}_{2} \mathrm{O}_{3}$ and $\mathrm{MgO}$ suggests a shallow marine environment of deposition for the limestone at Etono.

In general, the results obtained reveal that the Etono Limestone is suitable for cement production, building stone, filler purpose, agricultural use etc.

\section{ACKNOWLEDGEMENT}

The authors are grateful to Mr. Victor Nsidieti for his assistance in the geochemical analysis of Etono Limestone. Mr. Brendan Omini assisted in the field work and is gratefully acknowledged.

\section{REFERENCES}

Abimbola , A. F. and Akande, S. O., 1996. Alteration of carbonate host rocks of the Fluorite-Lead-Zinc mineralization at Arufu and Akwana. Middle Benue Trough, Journal of Mining and Geology. Nigeria. 32, 16-25.

Abdulraman, A. A. and Ayuba, A. M., 2007. Analysis of Limestone Samples Sourced from the Middle
Belt Zone of Nigeria. Int. Jour. Pure and Applied Sci., 1(2), 1-8.

Adeleye, D. R. and Fayose, F. A., 1978. Stratigraphy of the type section of Awi Formation, Odukpani area southeastern Nigeria, Jour., Min. Geol., 15: 33-37.

Brand, U., 1983. "Mineralogy and Geochemistry of Deep Sea Clay in the Atlantic Ocean and Adjacent Seas and Ocean". Geol. Soc. Amer. Bull. $76: 803-832$.

Chave 1954. Aspects of the Biogeochemistry of Magnesium in Calcareous Marine Organisms. Jour. Geol. 62, 266-283.

Ehinola, O. A. Oluwajana A., and Nwabueze, C. O., 2012. Depositional Environment, Geophysical Mapping and Reserve Estimation of Limestone Deposit in Arimogija - Okeluse Area, SouthWestern Nigeria. Research Journal in Engineering and Applied Sciences 1(1), 7-11.

Ehinola, O. A., Ejeh, O. I. and Oderinde, O. J., 2016. Geochemical Characterization of the Paleocene Ewekoro Limestone Formation, SW Nigeria: Implications for Provenance, Diagenesis and Depositional Environment. Geomaterials, 6, 61-77.

Ekwueme, B. N., 1985. The chemical and industrial quality of limestones and marls on the Calabar Flank, South Eastern Nigeria. Nigerian Journal of Mining and Geology. 22 (1 \& 2), 51 - 56.

Ekwueme, B. N., 1987. The occurrence, chemical composition and industrial quality of carbonate rocks in the Abini - Agoi area, South Eastern Nigeria. Nigerian Journal of Mining and Geology. 22 (1 \& 2), $51-56$.

Fatoye, F. B. and Gideon Y. B., 2013. Geology and mineral resources of the lower Benue Trough. Africa Geosciences Review, 20(1), 35 - 42.

Harrison O. J., Hudson J. M. and Cannel B., 1990: Appraisal of High Purity Limestone in England and Wales. A study' of Resources, N'eeds, Uses and Demands. Part 1 Resources Rep. Brit. Geol. Surv. Wf (92), pp. 19.

Ikhane, P. R, Folorunso, A. F., Nton, M. E. and Oluwalaanu, J. A., 2009. Evaluations of Turonian Limestone Formation Exposed at NIGERCEM-Quarry, Nkalagu, Southeastern Nigeria: A Geochemical Approach. The Pacific Journal of Science and Technology, 10 (2), $763-771$.

Iloeje, N. P., 1980. A new geography of West Africa. Longman, West Africa, 172pp.

Murat C., 1972: Stratigraphy and Paleogeography of the Cretaceous and Lower Tertiary in South-Eastern Nigeria. In: Dessauvagie T. F. J., Whiteman A. 
J. (Eds), African Geology. Ibadan University Press, pp 251-266

Nyong, E. E. and Ramanathan, R. M., 1985. A record of oxygen-deficient paleoenvironments in the Cretaceous of the Calabar Flank, SE Nigeria. Journal of African Earth Sciences, 3(4), pp. 455460.

Olaide, M. A., 1988. "Raw Materials for Cement Production after the Year 2000: Availabity, Suitability and Accessibility". National Workshop on Cement and Allied Products. Abeokuta, Nigeria.

Olatunji, J. A., 1989. Chemical characterization of Isaleosin marble, Kwara state. Geoscience Consultancy Report for Ministry of Commerce and Industry, Ilorin, Kwara state.

Petters, S. W. and Reijers, T. J. A., 1987. Cretaceous carbonates on the Calabar Flank. In: G. Matheis and $\mathrm{H}$. Schandelmeser (Editors), Current
Research in African Earth Sciences. Balkema, Rotterdam, pp. 155-158.

Pettijohn, F. J., 1984. Sedimentary Rocks, 4th edition. Harper and Row: New York, New York.

Reyment R. A., 1965: Aspects of the Geology of Nigeria. Ibadan University Press, p.133.

Seedman J.H.F. and Barlow S., 1989: The Durability of the Bath Building Stone. Proc. Ex. Ind. Conf. University of Birmingham, U.K. pp. 67.

Todd, T. W., 1966. Petrographic classification of carbonate rocks.Journal of Sedimentary Petrology 36(2), pp. 317-340.

Ugwu, A. C., 2021. Petrology and Gechemistry of Basement rocks in Ugep Southwest, Southeastern Nigeria. M. Sc. Thesis, Geology Department, University of Calabar, Calabar (Unpubl.). pp. 77.

Wikepedia, 2021 